\title{
Analisis Pemilihan Material Plat Lantai pada Proyek Perumahan menggunakan Metode AHP
}

\author{
Felicia T. Nuciferani ${ }^{1}$, Siti Choiriyah ${ }^{1}$, Bagus Kusuma Aji ${ }^{1}$ \\ ${ }^{1}$ Program Studi Teknik Sipil, Fakultas Teknik Sipil dan Perencanaan, Institut Teknologi Adhi Tama Surabaya \\ Email: *felicia@itats.ac.id
}

\begin{abstract}
Increasing the value of a product or service function to reduce costs without decreasing quality. Value engineering which functions to determine the alternative material on the floor plate in a housing project. The stages of the value engineering method consist of the information stage for the initial stage followed by the analysis, creative (alternative), development (AHP method) and recommendation stages. Data collection techniques in the form of structured interviews. Alternative floor plates used for comparison are conventional plates, Autoclaved Aerated Concrete, Keraton dak and steel deck-1000. The engineering value analysis is carried out based on the weighting of the quantitative criteria, the results of the normalized calculations and the quantitative criteria, which are then carried out with pairwise comparisons. The results showed that Autoclaved Aerated Concrete is an alternative material to be used for floor slabs with a value of 0.53 for the implementation cost criteria.
\end{abstract}

Keywords: AHP , Floor Slabs, Value Engineering

Peningkatan nilai pada fungsi produk ataupun jasa untuk pengurangan biaya tanpa penurunan kualitas. Rekayasa nilai yang berfungsi mengetahui alternatif material pada plat lantai di proyek perumahan. Tahapan metode rekayasa nilai terdiri tahap informasi untuk tahap awal yang diikuti oleh tahapan analisis, kreatif (alternatif), pengembangan (metode AHP) serta rekomendasi. Teknik pengambilan data berupa wawancara terstruktur. Alternatif plat lantai yang digunakan untuk perbandingan yaitu plat konvensional, Autoclaved Aerated Concrete, dak keraton dan steel deck1000. Analisis rekayasa nilai dilakukan berdasarkan pembobotan kriteria kuantitatif hasil perhitungan dinormalisasikan dan kriteria kuantitatif yang selanjutnya dilakukan dengan perbandingan berpasangan. Hasil penelitian bahwa Autoclaved Aerated Concrete merupakan alternatif material yang akan digunakan untuk plat lantai dengan nilai sebesar 0,53 untuk kriteria biaya pelaksanaan.

Kata Kunci : AHP, Plat Lantai, Rekayasa Nilai.

\section{Pendahuluan}

Rekayasa Nilai adalah proses pengambilan keputusan bersifat multidisiplin tersistematis serta terstruktur dengan analisis fungsi guna mencapai nilai terbaik (best value) sebuah proyek, definisi fungsi diperlukan guna capaian nilai tambah (value) dan penyediaan fungsi tersebut dengan biaya optimum, konsisten pada kualitas dan kinerja yang dipersyaratkan [1]. Tahapan pada rekayasa nilai melalui 5 tahap, sebagia berikut [2] : (1) Tahap Informasi, (2) Tahap Kreatif, (3) Tahap Analisis,(4) Tahap Pengembangan, dan (5) Tahap Rekomendasi atau Presentasi.

Analytical Hierarchy Process (AHP) merupakan metode pengambilan keputusan untuk penguraian masalah bersifat multi faktor atau multi kriteria kompleks menjadi hirarki. hirarki merupakan representasi sebuah masalah yang kompleks dalam suatu struktur multi level, level pertama adalah tujuandiikuti level selanjutnya yaitu faktor, kriteria, subkriteria hingga level terakhir dari alternatif menjadi bentuk hirarki yang jelas, terstruktur dan sistematis. [3] yaitu (1) Penyusunan pemilihan material dan (2) Penentukan faktor-faktor dalam pengambilan keputusan. 
Identifikasi faktor yang bertujuan identifikasi kepentingan dalam pengambilan keputusan yang bermanfaat dalam penyusunan hirarki berikut : (1) Struktur masalah dan penyusunan hierarki, (2) Melakukan pembobotan kriteria : Penentuan kriteria yang berhubung dengan tujuan utama serta penilaian tingkat kepentingan sehingga bobot criteria diperoleh, (3) Melakukan pembobotan subkriteria : Subkriteria yag telah ditentukan dengan tujuan sebagai nilai detail dari hasil kriteria guna pembobotan alternatif, (4) Melakukan pembobotan alternatif : Perlunya bobot alternatif guna mengetahui kondisi pada tiap alternatif, keperluan tersebut dituangkan dalam matriks profil dengan memuat penilaian tiap alternatif terhadap tiap kriteria, (5) Penyusunan bobot terhadap keseluruhan susunan, Penilaian alternatif pada tujuan utama dan perbandingan kriteria untuk mendapatkan bobot tiap alternatif : (6) Konsistensi :Pada Tahap ini dilakukan langkah-langkah [4] sebagai berikut : (a) Mean geometric, (b) Perbandingan berpasangan, (c) Matrik perbandingan berpasangan, (d) Sintesis, (e) Eigen value, (f) Indeks Konsistensi, (g) Consistency Ratio (CR).

\section{Metode}

Metode Penelitian menggunakan wawancara kepada expert dengan kriteria pengalaman dibidangnya minimal 3 tahun. Sedangkan untuk tahapan value engineering sebagai berikut :

\subsection{Tahap Informasi}

Berupa pengumpulan data dan Informasi (Rekapitulasi Anggaran Biaya).

\subsection{Tahap Analisis}

Pada tahap analisis menggunakan konsep cost saving yaitu :

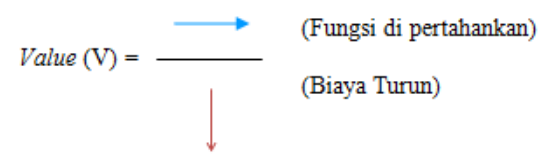

\section{Gambar 1. Konsep cost saving}

Analisis fungsi yang digunakan dengan mempertahankan fungsi sebagai pemisah ruangan tanpa mengubah fungsi utama plat lantai sebagai penyalur beban, dan bertujuan, untuk mengidentifikasi dan mengefisienkan biaya yang tidak perlu.

\subsection{Tahap Kreatif}

Beberapa alternatif yang digunakan untuk plat lantai sebagai berikut : (1) A0: Plat lantai asli atau plat lantai desain awal (plat lantai beton K-225 tebal $12 \mathrm{~cm}$ ), (2) A1: Plat lantai alternatif 1 (Pasangan lantai AAC (Autoclaved Aerated Concrete), (3) A2: mengetahui plat lantai alternatif 2 (Pasangan dak keraton $25 \mathrm{~cm} \times 22 \mathrm{~cm} \times 10 \mathrm{~cm}$ ), (4) A3: mengetahui plat lantai alternatif 3 (Plat lantai steel deck-1000, $12.000 \mathrm{~mm} \times 1000 \mathrm{~mm} \times 50 \mathrm{~mm}$ ), (5) Tahap Pengembangan : Pada tahapan pengembangan digunakan metode AHP, model pendukung keputusan akan menguraikan masalah multi faktor atau multi kriteria yang kompleks menjadi suatu hirarki. Hirarki didefinisikan sebagai representasi sebuah permasalahan kompleks dalam suatu struktur multi level. Level pertama adalah tujuan, yang diikuti level faktor, kriteria, subkriteria, dan seterusnya ke bawah hingga level terakhir dari alternatif. Pada penelitian ini terdapat 4 level hirarki yaitu : (a) level 1, berupa tujuan yaitu Plat Lantai, (b) Level 2, Berupa Kriteria yaitu kekuatan struktur, biaya pelaksanaan, waktu penyelesaian, biaya perawatan, metode pelaksanaan, estetika dan penampilan, (c) Level 3, Berupa subkriteria yaitu :
1. Kriteria Kekuatan Struktur
- Pembebanan struktur
- Nilai kuat tekan bahan atau material
- Kemampuan lebar bentangan maksimal
- Berat material, sehingga mengurangi beban bangunan 
2. Kriteria Biaya Pelaksanaan

- Biaya material, untuk aplikasi pelaksanaan

- Mengoptimalkan biaya penggunaan peralatan/ equipment untuk menunjang material/bahan saat pengerjaannya.

- Mengoptimalkan biaya kinerja meliputi: tenaga kerja dan jumlah pekerja yang dibutuhkan pada pelaksanaan.

- Perbandingan biaya awal di proses pelaksanaan.

3. Kriteria Waktu Penyelesain

- Kemampuan mengoptimalkan waktu, sesuai dengan schedule yang sudah ditetapkan.

- Mengoptimalkan material (mengurangi waste)

- Mengurangi resiko keterlambatan akibat kesalahan penyedia barang dan jasa

- Ketepatan dan kerapihan hasil pegerjaan waktu penyelesaiannya.

4. Kriteria Metode Pelaksanaan

- Kemudahan pengerjaan dan pengaplikasiannya dilapangan

- Kecepatan pengerjaannya saat diaplikasikan dilapangan.

- Mudah dimobilisasi diruang terbatas, sesuai daerah urban yang padat

- Kesesuaian jumlah dalam ketepatan pengiriman

5. Kriteria Biaya Perawatan

- Perawatan tidak memerlukan biaya peralatan yang besar.

- Perawatan yang mudah tidak memerlukan biaya SDM yang banyak.

- Proses perawatan tidak memakan waktu panjang agar bisa dioptimalkan.

- Biaya perawatan sedikit, saat terjadi kerusakan/ kecacadan dalam hasil pengerjaannya.

6. Kriteria Estetika dan Penampilan

- Desain Material yang Mudah dalam pengaplikasinya dilapangan

- Kualitas bahan/material, untuk meminimalisir kecacadan dalam hasil pengerjaannya.

- Mempunyai nilai estetika yang baik

- Kemampuan daya redam suara

(c) Level 4, berupa material plat lantai beton (konvensional), AAC, dak keraton, lantai steel deck-1000

\subsection{Tahap Rekomendasi atau Presentasi}

Rekomendasi tertulis atau lisan ditunjukan pada pihak terlibat dalam pemahaman alternatif-alternatif terpilih pada metode rekayasa nilai.

\section{Hasil dan Pembahasan}

Pada tahap analisis didapatkan pekerjaan plat lantai beton K-225 dengan ketebalan $12 \mathrm{~cm}$ yang dapat dilakukan proses rekayasa nilai guna pengendalian aktivitas biaya sehingga dilakukan pengolahan dengan menggabungkan antara metode rekayasa nilai dan analytical hierarchy process. Pada tahap analisis cost/worth menunjukan bahwa biaya yang dikeluarkan untuk pekerjaan plat lantai memiliki nilai dua kali lipat dibandingkan manfaat yang dihasilkan dengan nilai sebesar 1,69 sehingga sangat memungkinkan untuk dilakukan rekayasa nilai.

AHP merupakan metode penanganan masalah yang kompleks serta tidak terstruktur, tersusun dalam bentuk hierarki, dengan skala penilaian 1 sampai 9. AHP digunakan untuk menentukan prioritas beberapa kriteria dengan menggunakan perbandingan berpasangan. analisis setiap kriteria hingga perhitungan Consistency Index (CI) dan Consistency Ratio (CR). Dalam pengambilan keputusan perlu diketahui seberapa benar konsistensi dengan kriteria konsistensi 10\%, kemudian hasil penghitungan dinyatakan benar, dan dapat diartikan bahwa responden konsisten.

Tahapan berikutnya, dilakukan sintesis guna mendapatkan bobot alternatif secara keseluruhan berdasarkan kriteria tetapi terlebih dahulu dilakukan perhitungan bobot (local priority). Hasil dari 
global priority didapatkan dengan cara pengalian local priority dengan prioritas level di atasnya (parent criterion). Hasil dari global priority tiap alternatif dapat dilihat pada tabel 1

Tabel 1. Prioritas Alternatif Keseluruhan

\begin{tabular}{lll}
\hline Alternatif & Bobot & Prioritas \\
\hline Plat Lantai Konvensional & 0.1475 & IV \\
\hline Plat Lantai AAC & 0.4262 & I \\
\hline Plat Lantai Dak Keraton & 0.2332 & II \\
\hline Plat Lantai Steel Deck-1000 & 0.1931 & III \\
\hline
\end{tabular}

Pada tabel 1 didapatkan bahwa plat lantai AAC mendapatkan nilai bobot 0,4262 berarti prioritas utama yang terpilih. Pemilihan plat lantai didasarkan masing-masing kriteria tertuangkan pada tabel 2

Tabel 2. Bobot Alternatif (Plat Lantai) Berkenaan dengan Semua Kriteria

\begin{tabular}{|c|c|c|c|c|c|}
\hline Kriteria & $\begin{array}{l}\text { Plat Lantai } \\
\text { Konvensiona } \\
1\end{array}$ & $\begin{array}{l}\text { Plat Lantai } \\
\text { AAC }\end{array}$ & $\begin{array}{l}\text { Plat Lantai } \\
\text { Dak } \\
\text { Keraton }\end{array}$ & $\begin{array}{l}\text { Plat Lantai } \\
\text { Steel Deck- } \\
1000\end{array}$ & Jumlah (N) \\
\hline Kekuatan Struktur & 0.29 & 0.23 & 0.12 & 0.36 & 1.00 \\
\hline Biaya Pelaksanaan & 0.07 & 0.53 & 0.33 & 0.07 & 1.00 \\
\hline Waktu Penyelesaian & 0.08 & 0.52 & 0.22 & 0.19 & 1.00 \\
\hline Metode Pelaksanaan & 0.13 & 0.49 & 0.22 & 0.15 & 1.00 \\
\hline Biaya Perawatan & 0.09 & 0.48 & 0.26 & 0.17 & 1.00 \\
\hline $\begin{array}{l}\text { Estetika dan } \\
\text { Penampilan }\end{array}$ & 0.19 & 0.25 & 0.21 & 0.35 & 1.00 \\
\hline
\end{tabular}

Berdasarkan tahapan AHP dengan struktur hirarki bertingkat untuk pemilihan plat lantai bahwa biaya pelaksanaan unggul pada beberapa besar kriteria dan Bobot Alternatif (Plat Lantai) Berkenaan terhadap Kriteria bobot terbesar yaitu biaya pelaksanaan sebesar 0,53 dari bobot kriteria biaya pelasanaan terhadap alternatif ( plat lantai AAC). Maka tahap akhir perhitungan yaitu rekomendasi untuk material plat lantai digunakan plat lantai AAC dari segi biaya pelaksanaan.

\section{Referensi}

[1] Ariadi, "Faktor Kunci Sukses Penerapan Value Engineering (Ve) Pada Bangunan Gedung Di Indonesia," Rekayasa Sipil, vol. 6, no. 2, pp. 77-85, 2017.

[2] M. M. Pontoh, H. Tarore, R. J. M. Mandagi, and G. Y. Malingkas, "Aplikasi Rekayasa Nilai Pada Proyek Konstruksi Perumahan ( Studi Kasus Perumahan Taman Sari Metropolitan Manado Pt . Wika Realty )," J. Tek. Sipil, vol. 1, no. 5, pp. 328-334, 2013.

[3] M. F. N. Aulady, F. T. Nuciferani, and Y. Pratama, "Pemilihan Subkontraktor pada Proyek Pengembangan Rumah Sakit Dr. Soetomo dengan Menggunakan Metode Analytical Hierarchy Process," Semin. Nas. Sains dan Teknol. Terap. IV, p. A.93-A.98, 2016.

[4] A. Munthafa and H. Mubarok, "Penerapan Metode Analytical Hierarchy Process Dalam Sistem Pendukung Keputusan Penentuan Mahasiswa Berprestasi,” J. Siliwangi, vol. 3, no. 2, pp. $192-$ 201, 2017. 